\title{
Assessment and Documentation of Indigenous and Introduced Soil and Water Conservation Measures in Some Parts of Southern Ethiopia
}

Dawit Kanito ( $\nabla$ dawitkanito.skm@gmail.com )

SARI: Southern Agricultural Research Institute https://orcid.org/0000-0002-4030-9331

Tsegaye Bekele

SARI: Southern Agricultural Research Institute

Tesfaye Dawit

SARI: Southern Agricultural Research Institute

Seyfu T/yohannes

SARI: Southern Agricultural Research Institute

\section{Research}

Keywords: Southern Ethiopia, soil erosion, indigenous conservation practices, Agro-ecology, introduced conservation practices

Posted Date: January 21st, 2021

DOI: https://doi.org/10.21203/rs.3.rs-150719/v1

License: (9) (1) This work is licensed under a Creative Commons Attribution 4.0 International License. Read Full License 


\section{Abstract}

\section{Background}

In Ethiopia, soil and water conservation activities were started after the famines of 1973 and 1985. Following this, different conservation measures were implemented by the government, non-government organizations, and the community to facilitate the optimum level of production from a given area of land while keeping soil loss below a critical value. This study was conducted at Wolaita, Hadiya, Kambata Tambaro, and Dawro Zones of Southern Ethiopia. It was designed to identify indigenous and introduced soil and water conservation practices, measure and describe identified practices, and document the identified practice for further reference.

\section{Results}

The result revealed that three types of soil and water conservation practices namely biological, physical, and agronomical were implementing in the study areas. The result from the technical evaluation showed that soil bund and fanya juu has channel depth and embankment height lower than the recommended dimension. The result also indicated that less attention was given to indigenous soil and water conservation practices. Besides, the sustainability gap in constructed conservation practices was widely perceived.

\section{Conclusions}

Farmers in the study area are well acquainted with soil erosion, its cause, and consequent reduction in land productivity. They confirm that implementing SWC measures are insurance to sustain and boost soil fertility and land productivity. In southern Ethiopia government and peoples were invested much more time, money, knowledge, and manpower to construct SWC measures. But, year by year structures get damage and yet seem not substantial to achieve the sector of sustainable agriculture. Besides, the study revealed that identified practices such as traditional cutoff drain, fanya juu, soil bund, stone-faced soil bund, fanya juu, brushwood, and gabion check-dams have technical, social, and institutional difficulties. The major gap observed with indigenous conservation practices is, it had been taken less attention by different stakeholders including GOs, NGOs, and research institutes. As a result, their respective dimension was not modified, effective measures were not up-scaled and circulated to other areas having similar agroecology and farming system. Thus, apparently, traditional conservation measures are aggravating soil erosion and their construction did not consider the downstream effect on dwelling community, water bodies, and aquatic lives.

\section{Background}

In Ethiopia, Soil and water conservation (SWC) activities were started after the famines of 1973 and 1985 with a different program launched by the government and non-government organizations (GOs and NGOs) from which food-for-work program was implemented for a long time (Hoben, 1996). Following this program, different physical and biological soil and water conservation measures were implemented by community collective action as well as a family level trial. On the other way, different land enhancing technologies and practices have been introduced by research institutions, extension, and other development practitioners in the region (Wagayehu and Lars, 2003).

Indigenous soil and water conservation is the method used by different farmers to facilitate the optimum level of production from a given area of land while keeping soil loss below a critical value. The soil loss tolerance value is defined as the rate of erosion at which soil fertility can be maintained over at least 25 years (Hurni, 1983). Indigenous soil and water conservation practices have very often been ignored or underestimated by development agents, researchers, soil conservationists, and government staff (IFAD, 1992). Although the objectives of knowing indigenous soil and water conservation practices give us an understanding of farmers' way of thinking about the measures (Hudson, 1992). Farmers use several indigenous SWC technologies to prevent the problem of soil erosion. Among these is cutoff drains, leaving crop residues in the field, distribution of manure, contour farming, fallowing, planting root crops by preparing bunds, tree planting on slope farm, use of trash lines on contour, row planting, alley cropping, intercropping, strip planting, and plantation of Sisal (Agave sisalana Perrine) and euphorbia (Euphorbia classenii) on the farm etc. According to Genene M. and Abiy G. (2014), most of the farmers in south western Ethiopia practices introduced and indigenous SWC activities like; contour farming, furrow making, residue leaving, agronomic practices, putting trash lines on contour etc. Broadly the conservation measures are classified as agronomic measures, physical /structural/ measures and biological/vegetative/ measures (IFAD, 1992).

It should be emphasized that before introducing a new technology it is necessary to check whether local soil and water conservation measures already exist and why and how farmers apply these indigenous technologies. If such technologies exist and continue to be applied by farmers, then, providing they have not been introduced and maintained by legal force and state authority, they can be considered successful and on investigation will be found to provide tangible benefits. Understanding the reasons why farmers use such technologies, i.e. the production and conservation benefits they get from them, is the key to the successful introduction of any "new" technology, which must at least match and preferably improve on the benefits to be obtained from the existing ones (CARDI, 2010).

The effect of SWC measures in reducing soil loss generally varies with soil type, land use, land cover, topography, climate, and intensity of the measures. Among the factor, the major contribution for reducing erosion is from the farming system in general and land use land cover specifically. In this regard, the major factors are related to the daily activity of landowners/farmers/. Therefore, they protect their soil indigenously for their crop productivity. Different authors assessed many indigenous SWC practices that can reduce soil loss however it was not organized as a form of integrating its historical analysis, source, and property, technical social, economical, and cultural aspects. For this reason, this project was initiated to identify and investigate different indigenous and introduced SWC, to measure and describe identified SWC practices that could add value to reducing soil erosion and increasing moisture on farms so that, it will be documented for future development. 


\section{Methods}

The Southern Nations, Nationalities and Peoples' Region (SNNPR) is one of the nine regional states of Ethiopia located in the south and south-western part. Geographically it is situated between the coordinates of $4^{0} 27^{\prime}$ and $8^{0} 30^{\prime} \mathrm{N}$ and $34^{\circ} 21^{\prime}$ and $39^{\circ} 11^{\prime}$ E with altitude ranging from 376 to 4207 masl and with mean annual temperature ranging from $15^{\circ} \mathrm{c}$ to $30^{\circ} \mathrm{c}$ (BoSP, 2004). It covers approximately a total area of $110931.9 \mathrm{~km} 2$ divided into 14 administrative zones and 136 districts. It has a very diverse agro-ecology classified as lowlands, mid, and highlands covering $57.4,34$, and $8.6 \%$ respectively. SNNPR has 13 major and 19 sub-agro-ecological zones (IFPRI, 2006). The rainfall pattern of the region is bimodal with small rain in the dry season and high rainfall in the main rain season with mean annual rainfall ranging between $400 \mathrm{~mm}$ in the extreme south of Debub Omo zone and over $2200 \mathrm{~mm}$ in the west in Sheka and Kaffa zones. SNNPR has a total population of 15.04 million of which $89.72 \%$ of the people are living in rural areas and $10.28 \%$ are urban dwellers (CSA, 2008). The population density ranges from 4 to 900 persons per square kilometer. The average landholding size of the region is estimated to be 0.75 ha which lies below the national average (1.2 ha) (CSA, 2010). The region has typical ethnic-cultural diversity comprising more than 56 distinct nationalities living in different agro-ecology all having their own culture, farming system, indigenous knowledge of managing natural resources.

The study was conducted in four Zones of Southern Ethiopia namely Wolaita, K/Tambaro (Kambata Tamabaro), Hadiya, and Dawro where Areka Agricultural Research Center (AARC) implements different research activities.

\section{Sources of Data}

Data for this study were captured from two sources: primary and secondary sources. The main primary sources of data were farmers. Hence, field observation, characterization of structures, focus group discussion, and interviews with selected farmers and other informants were primary data sources. Besides, zonal and district agricultural experts, Kebele administrators, and Development agents (DAs) provided primary information. In addition to these primary data sources, some secondary sources of data collection methods were used in this study. Secondary sources of information used for this study include published materials such as reports, official records, and project reports.

\section{Sampling Procedures}

It is a fact that, at different agro-ecological zones, different SWC practices has been implementing. As a result, representative sample districts and kebeles were purposely selected from different agro-ecological zone under AARC mandate areas of Southern Ethiopia. To select representative districts and kebeles, a detailed discussion was organized with zonal and district agricultural department with a selected multi-disciplinary team (natural resource management, crop, animal science, socio-economic, and irrigation) who have experience about all districts, having detailed information and share on issues of farming system and SWC measures.

During the first stage, two districts from each zones and eight districts from all zones were purposely selected, because they were identified as having a relatively high rate of SWC practices. Similarly, at the next stage, three kebeles per district and twenty-eight kebeles in total were purposely chosen from respective agro-ecological zones, where again the same appearance of use programs was identified as the reasons. After all, for a detailed study, sample households from representative kebeles were purposely selected based on the extent that they perform and their know-how on SWC practices.

\section{Method of data collection}

The following data collection tools were employed to gather relevant information.

\section{Field Observation}

Field observation was undertaken to identify and verify acquired SWC practice during a focus group discussion (FGD), household (HH) survey, and key informant interview (KII). Overall aspects of SWC practices were observed, measured, and described as well. As a result, the researchers' opinion based on field visit is incorporated.

\section{Formal Interviews}

The largely used instrument for data collection was a formal interview with carefully constructed questions. Hence, most farmers are local language users; enumerators were selected for formal interviews. Selected enumerators from each study site were fluent in speaking local languages and Amharic as well. Before the implementation of the survey, enumerators were trained and tested for their clarity and understanding of the questions. Henceforth, the survey was employed.

\section{Focus group discussion}

During FGD two ways of communication were conducted between participants and interviewers to make the process of data collection more effective. In this way, participants could also ask questions on problems of soil erosion and soil conservations. FGD was conducted in all study areas. Selected questions from the same formal questionnaire and additional questions were also included that was supposed to be necessary to capture relevant information for focus group discussions. FGD comprises 8 farmers in every kebeles (2, 2, 2, 2 elders, youth, female, and model HH respectively).

\section{Results}

The results from the household survey, key informant interviews, field-level observation, and focus group discussion shows that, government organization, NGOs, and communities in separate and collaboration implementing three types of SWC conservation measures. 
The study revealed that farmers in the study areas implement three-folds of SWC measures. The one is a biological conservation measure including area closure, grass strip, bund stabilizer, and live fence.

\section{Area closure}

The study revealed that, to halt and rehabilitate natural resource degradation, area closure as a biological conservation measure is exercising in Hadiya, $\mathrm{K} /$ Tambaro, Dawro, and Wolaita Zones of Southern Ethiopia. In combination with closed areas, to facilitate regeneration of the environment, they had been implementing physical conservation measures mostly eyebrow basin, micro basin, gabion, brushwood and/stone check dams, soil bund, stone-faced soil bund, stone bund, and trenches.

\section{Grass strip}

Uncommon implementation of grass strips as SWC measures in different study areas was observed. The researchers investigated that it has a dimension of $30-80 \mathrm{~cm}$ width along the contour on the field. Two types of grasses namely Desho and Elephant are commonly exercised in the study areas.

\section{Bund Stabilizer}

The result from group discussion, $\mathrm{HH}$ survey, KII, and transect walk revealed that farmers in the study area commonly practice different stabilizers. They integrate banana, desho grass, Elephant grass, and Cajanus cajan with constructed mechanical measures. Farmers state that integrating biological measures has several benefits besides reducing and protect runoff and soil erosion; forage, food, income source, soil moisture improvement, and increases bund life span.

\section{Live fencing}

The study revealed that farmers in the study area traditionally plant shrubs across the slope and around farm plots to control and prevent soil erosion and to protect the farm from unexpectedly damaging animals. This practice is very common in Woalita, Dawro, K/Tambaro, and Hadiya Zones of Southern Ethiopia.

\section{Physical Conservation Measures}

\section{Soil bund}

Soil bund is an embankment constructed from the soil along the contour with a water collection channel or basin at its upper side. It is constructed by throwing soil dug from the basin downslope. It aims to reduce runoff, halt erosion, increase infiltration, and reduce slope steepness. During construction, it followed its technical standard; however, the sustainability problem is boldly observed due to free grazing, maintenance gap, and poor stabilization. During field measurement and characterization, the researcher obtained the following average dimensional data. It has a tied ridge of $10 \mathrm{~m}$ interval and a berm of about $15 \mathrm{~cm}$ from the embankment.

Table 1 Structural dimension of soil bund after construction

\begin{tabular}{|c|c|c|c|c|c|c|c|c|c|c|c|c|c|c|c|c|c|c|c|c|}
\hline $\begin{array}{l}\text { Structure } \\
\text { name }\end{array}$ & Soil & ounc & cm) & & & & & & & & & & & & & & & & & \\
\hline \multirow[t]{2}{*}{ Location } & \multicolumn{5}{|c|}{ Wolaita } & \multicolumn{5}{|c|}{ Hadiya } & \multicolumn{5}{|c|}{$\mathrm{K} /$ Tambaro } & \multicolumn{5}{|c|}{ Dawro } \\
\hline & $\mathrm{D}$ & W & $\mathrm{EH}$ & EBW & ETW & D & W & $\mathrm{EH}$ & EBW & ETW & D & W & $\mathrm{EH}$ & EBW & ETW & D & W & $\mathrm{EH}$ & EBW & ET \\
\hline Dimension & 45 & 30 & 40 & 70 & 32 & 42.1 & 60 & 33.6 & 94.3 & 40.4 & 50 & 50.3 & 42 & 86.3 & 31.25 & 36.4 & 44.3 & 21 & 81.7 & 25 \\
\hline
\end{tabular}

Where; Depth (D), Width (W), Embankment bottom width (EBW), Embankment top width (ETW), and Embankment height (EH).

\section{Cutoff drain}

Farmers construct cutoff drain across the slope to intercept surface runoff and convey safe disposal from cropped land, roadsides, and homesteads to divert uncontrolled runoff to an out-late such as waterways, rivers, and preexisting gullies. Sampled respondents stated that, traditionally, farmers in the study area also divert water from their cropped land to boundaries. As the result, diverted water creates and exacerbates gullies, reduce the productive land size, and block the free movement of man and livestock from field to field. The way of construction is graded at planting and at heavy rainfall time with a spacing of necessity. They also construct it around roadsides and homesteads to divert uncontrolled runoff. On croplands, they construct commonly by oxen and its dimension is nearly equivalent to the size of "Mofer" which is about $30 \mathrm{~cm}$ * $30 \mathrm{~cm}$ depth and width. It has been exercising widely at Wolaita, Dawro, Hadiya, and K/Tambaro zone of southern Ethiopia. However, farmers with no oxen construct by hand using a fork, spade, and other digging materials. Locally it is named "Boyea" (Wolaita and Dawro). They believe that the construction of the cutoff drain has two-fold advantages such as production and conservationoriented. They intend to conserve inputs (seed and fertilizer) and soil loss and prevent water from entering the house. The same study did by Habtamu, (2014) agrees with this study.

Besides, farmers implement diversion ditch based on standard guidelines developed by the Ethiopian Ministry of Agriculture. They do so for a similar objective as the traditional one. However, the difference is that of technical standards and appropriateness of the structures. 


\section{Stone Bund}

Farmers construct cutoff drain across the slope to intercept surface runoff and convey safe disposal from cropped land, roadsides, and homesteads to divert uncontrolled runoff to an out-late such as waterways, rivers, boundaries, and preexisting gullies. Besides, farmers implement diversion ditch based on standard guidelines developed by the Ethiopian Ministry of Agriculture. They do so for a similar objective as the traditional one. However, the difference is that of technical standards and appropriateness of the structures.

Table 2 shows the technical status of the stone bund at some zones of SNNPR

\begin{tabular}{|c|c|c|c|c|c|c|c|c|c|c|c|c|c|c|c|c|}
\hline \multicolumn{17}{|l|}{ Structure name } \\
\hline \multirow[t]{2}{*}{ Location } & \multicolumn{4}{|c|}{ Wolaita } & \multicolumn{4}{|c|}{ Hadiya } & \multicolumn{4}{|c|}{$\mathrm{K} /$ Tambaro } & \multicolumn{4}{|c|}{ Dawro } \\
\hline & $\mathrm{F}$ & $\mathrm{HB}$ & TW & BW & $\mathrm{F}$ & $\mathrm{HB}$ & TW & BW & $\mathrm{F}$ & $\mathrm{HB}$ & TW & BW & $\mathrm{F}$ & $\mathrm{HB}$ & TW & BW \\
\hline Technical aspect & 30 & 80 & 30 & 50 & - & - & - & - & 30 & 50 & 30 & 75 & 30 & 71.3 & 25.7 & 66.3 \\
\hline
\end{tabular}

Where; Foundation of the bund (F), Height of bund (HB), Top width of bund (TW), and Bottom width of the bund (BW)

\section{Fanya juu}

This is an embankment constructed by throwing the soil dug from basin to uphill and the term was coined from Swahili language; meaning "throwing up-hill" (Woldeamlak, 2003). The researcher investigated that farmer's in the study area do not exercise fanya juu widely as other physical measures. The principal reason behind this is its ease of destruction and soil become refilled into an excavated ditch by some of driving forces like rainfall, erosion, and animals.

Table 3 Dimensional characteristics of constructed fanya juu bund at K/Tamabaro Zone

\begin{tabular}{|c|c|c|c|c|c|c|c|c|c|c|c|c|c|c|c|c|c|c|c|c|}
\hline \multicolumn{21}{|c|}{ Structure name } \\
\hline \multirow[t]{2}{*}{ Location } & \multicolumn{5}{|c|}{ Wolaita } & \multicolumn{5}{|c|}{ Hadiya } & \multicolumn{5}{|c|}{$\mathrm{K} /$ Tambaro } & \multicolumn{5}{|c|}{ Dawro } \\
\hline & $\mathrm{D}$ & W & $\mathrm{EH}$ & EBW & ETW & $\mathrm{D}$ & W & $\mathrm{EH}$ & EBW & ETW & D & W & $\mathrm{EH}$ & EBW & ETW & $\mathrm{D}$ & W & $\mathrm{EH}$ & EBW & ETW \\
\hline Dimension & - & - & - & - & - & - & - & - & - & - & 50 & 50 & 47.5 & 77.5 & 30 & - & - & - & - & - \\
\hline
\end{tabular}

Where; Depth of the channel (D), Width of the channel (W), Embankment height (EH), Embankment bottom width (EBW), and Embankment top width (ETW).

\section{Terrace (bench and hillside)}

The study revealed that the community in the study area directly construct a terrace on sloppy and mountainous land if they have enough manpower and input materials. The respondents dictated that they properly maintain constructed soil bund, fanya juu, grass strip, and stone bunds which gradually changed into bench terrace.

\section{Stone-faced soil bund}

Survey result revealed that, based on stone availability, farmers in the study areas commonly reinforce the lower bank of the bund with a stone riser on both on-farm and communal lands. The height of the riser depends on the stone in the area.

\section{Brushwood check-dam}

These are vegetative measures constructed from small wood branches and poles, interwoven together and have a short life span, and easy to construct using cheap materials. These are constructed in small gullies less than 2 meters. In the study areas farmers commonly practice single row brushwood check-dam, however; it depends on the availability of local materials. Poor in the design of check-dam and non-regenerative material used are the major gaps observed regarding constructed check-dams. Besides, the poles used do not bit the required diameter, are not straight enough, are not combined with multipurpose plant species, and plant species used were not ideal. As a result, it becomes cracked and the gully is not well conserved.

\section{Gabion check-dam}

Gabions are rectangular boxes of varying sizes and are mostly made of galvanized steel wire woven into the mesh. Stabilization of gullies involves the use of appropriate structural and vegetative measures in the head, floor, and sides of the gully. The study revealed that the gabion check dam had been practicing to rehabilitate and prevent further expansion of gullies in different study areas. The gap observed in the Hadiya case is that of constructed gabion check-dam lacks with side key foundation and spillway. As a result side wall sliding is majorly observed.

\section{Trench}

Trenches are large and deep pits constructed along the contours with the main purpose of collecting and storing rainfall water to support the growth of trees, shrubs, cash crops, and grass or various combinations of those species in moisture stressed areas (MoA, 2012). In the study, area trenches were constructed 
in a staggered manner.

\section{Micro basin}

Micro basins are small structures constructed by excavating half-circle shaped basins for tree planting. In the study areas, there is the practice of micro basins for the cultivation of fruit trees but the practice is not widely exercised and is very limited to closed areas. The construction of micro-basins is aimed to conserve water for plantation. The spacing between basins is determined by plant spacing and the distance along the slope.

Table 4 Dimensional characteristics of constructed Micro basin at K/Tamabaro Zone

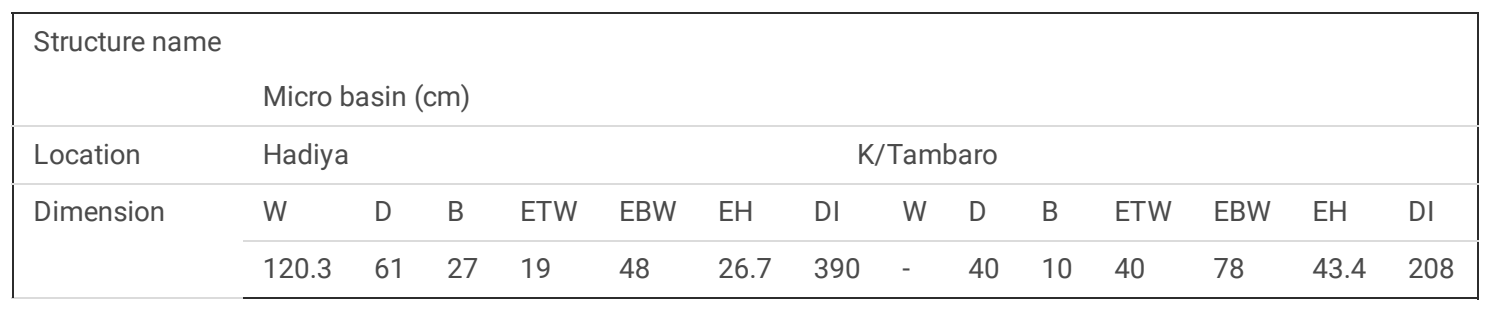

Where; D, W = depth and width of the basin; ETW, EBW, EH = Embankment (top and bottom) width and Embankment height; B, DI = burm and diameter of the basin respectively.

\section{Pond}

The result from a sampled household, focus group discussion, and field observation revealed that farmers in the study area are excavating ponds as communal property. They use it as a water source for livestock and as an irrigation source for high-value vegetable crops. To control water seepage they install plastic sheets as shown in the figure below.

\section{Agronomic Conservation Measures}

\section{Contour furrow (Shilshalo)}

In our country Ethiopia, harrowing (Shilshalo) is common practice under the maize field to manage weeds. The study revealed that farmers under this study areas commonly practice Shilshalo not only to control weed but also to harvest rainwater, enhance infiltration, and to overcome moisture deficit for the crop during a dry spell.

\section{Mulching and crop residue management}

Farmers in the study area traditionally use leaving crop residue on the field. They said that it is preferable because it is less expensive and demands a few laborers, might not obstacle oxen plow, and make movement easier. In the study areas, commonly used materials for mulching are Enset residue (at the home garden and Enset field), banana, maize, and sorghum. Furthermore, they use common bean residue as green manure and harvest teff, wheat, and barley about $20 \mathrm{~cm}$ above the ground to reduce the susceptibility of the soil to erosion.

\section{Contour farming}

Contour cultivation is practiced in nearly all the countries of East and South Africa. From the response of focus group discussion and field observation, farmers in the study area practice contour farming across the slope. They implement it during all farm operations. Farmers viewed in the group discussion that, contour farming is a good option to slow and impede downward water flow, increase rainwater retention and infiltration, and avoid erosion. A study held by Bancy, (2007) confirms that contour farming on a slope range of 4 to 6 percent can reduce water loss (runoff) by 50 percent and soil loss by about 50 percent compared to up and downhill cultivation.

\section{Improved Fallowing}

The study revealed that farmers use fallowing primarily as a means of reclaiming the productive potential of the soil. During FGD, farmers pointed out that, fallow period and land size depend on the size and availability of land owned by households i.e., farmers with relatively large land size widely exercise fallowing. Whereas, farmers' having limited land size exercise rarely and/or no fallowing.

\section{Discussion}

The efforts made in the last two decades especially in the past few years in the rehabilitation of degraded land resources in-country Ethiopia were tremendous. Most of the measures implemented are physical conservation measures and had created a tremendous impact. But these alone do not directly influence biomass production (Hailay T., 2012). As a result, nowadays, government organizations, NGOs, and communities in separate and collaboration are implementing biological, physical, and agronomical conservation measures. Farmers in the study areas had been implementing biological conservation measures. The importance of the biological conservation measures lies in the fact that these measures directly influence the biomass production and the protective plant cover on the land reducing the loss of soil and water and at the same time these are the measures which are the source of our needs of survival and prosperity (Hailay T., 2012). 
In central Zones of Southern Ethiopia due to high population density and land shortage, farmers cultivate steep and marginal lands to satisfy the increasing food demand of the rapidly growing population. These factors significantly contribute to a high rate of land degradation. As a result, different stakeholders are still taking action from the 1970s to enhance sustainable agriculture with an embryonic emphasis on the implementation of SWC measures. The finding indicated that farmers in the study areas implementing area closure with physical conservation measures facilitate rehabilitation (figure 1). Tiki et al. (2015) reported that even if simple area closure without SWC can be an effective method to rehabilitating degraded hillsides incorporating SWC measures is the preferable way to speed up the rehabilitation period. According to figure 2 , the effect of grass strip on sediment reduction was significant, and its effect increase with time as its biomass increment. Zheng et al. (2005) reported that the effect of appropriate vegetation measures on runoff and sediment reduction will become increasingly significant with time. Farmers who hosted grass strips expressed their appreciation towards its role in minimizing soil erosion and runoff, forage, and economic source. Though grass strips are list cost and labor-consuming measures, the effort made by farmers to implement grass strip founds to inconsistency. Besides, in the study areas, the practice of grass strip is not common due to free grazing and farmer's awareness gap.

In the study areas, farmers construct soil bund by community mass mobilization and at the family level from February to December of each year. The research finding indicated that GO, NGOs, and other relevant organizations having the responsibility of reducing land degradation had been supporting the establishment and strengthening of local institutions and farmers to exercise soil bund. Framers pointed out that soil bund is the most widely and intensively used SWC measure in the study areas (figure 5). In FGD, farmers and key informants were asked what type of bund they construct. They responded that they are popular with level bund but in the rare case, they also practice graded bund if it becomes a must due to conditions (excess runoff, soil with stick nature) and based on the availability of waterway. This study agrees with the study held by Wolde-Aregay1996; Lundgren and Taylor 1993; cited in Bancy 2007. It aims to reduce runoff, halt erosion, increase infiltration, and reduce slope steepness.

The study revealed that in the study areas farmers construct cutoff drains at planting and at a rainy time with a spacing of necessity to conserve farmland below. On croplands, they construct commonly by oxen and its dimension is nearly equivalent to the size of "Mofer" which is about $30 \mathrm{~cm}$ * $30 \mathrm{~cm}$ depth and width. It has been exercising widely at Wolaita, Dawro, Hadiya, and K/Tambaro zone of southern Ethiopia. However, farmers with no oxen construct by hand using a fork, spade, and other digging materials. Locally it is named "Boyea" (Wolaita and Dawro). They believe that the construction of the cutoff drain has two-fold advantages such as production and conservation-oriented. They intend to conserve inputs (seed and fertilizers) and soil loss and prevent water from entering the house. The same study did by Atnafe et al. (2015) and Habtamu, (2014) agrees with this study. Sampled respondents stated that, traditionally, farmers in the study area divert water from their cropped land to boundaries. As the result, diverted water creates and exacerbates gullies, reduce the productive land size, and block the free movement of man and livestock from field to field. Besides, farmers construct cutoff drains based on standard guidelines developed by the Ethiopian Ministry of Agriculture. However, the difference is that of technical standards and appropriateness of the structures. Farmers also construct fanya juu in the fields sloping above 10\%. Figure 7 shows farmers' adoption of fanya juu on their farm plot. The construction of Fanya juu takes less space than soil bunds and accelerates bench development, thus, a complaint about space can be greatly reduced with Fanya juu terraces (WFP, 2005). During the FGD and HH survey, selected respondents were asked when, how, and why to construct fanya juu terrace. Respondents replied that they construct fanya juu from February to December by a campaign designed by trained farmers and DAs. It aims to reduce and stop erosion and increase the water holding capacity of the soil to enhance land productivity.

Farmers and DAs reported that well managed and maintained soil bund, fanya juu, grass strip, and stone bunds were gradually converted to bench terrace. The same study did by Bancy, (2007) indicates this result. However, in some cases, hillside terraces were constructed directly on sloppy and mountainous land. They responded that, before construction, they make sure that labor and inputs available are satisfactory. If there is ample stone, they prefer to use it as a raiser. If insufficient or no stone, the raiser becomes the soil as shown in figure 8 above. Before construction, topsoil was removed and deposited somewhere else. Later after the level slope of the plot is achieved, the topsoil gets fill back. During construction by stone as raise, they excavate foundation having about $30 \mathrm{~cm}$ depth and width. The height of the raiser above ground is around $75 \mathrm{~cm}$. At the base, they arrange stones of different sizes i.e., large size stones mixed with smaller to not collapse easily. Finally, for some seasons, legume grasses and shrubs like oat, vetch, faba bean, field peas, and Cajanus cajan are planted to restore farmland. Hu et al. (2016), found that the presence of legume species might indicate recovery of species richness and promotion of succession on the degraded grassland. These implied that planting legumes could be an effective measure to accelerate the recovery process of the degraded lands. The result indicated that farmers in the study areas also use compost on degraded farmlands to facilitate the rate of rehabilitation. $\mathrm{KI}$ and farmers pointed out that their pillar goal behind the construction of the terrace is to protect the plot from uncontrolled runoff and erosion, retain water, increase natural resource base, and production.

Discussion held with a focus group and key informant revealed that they construct check dams to reduce runoff velocity, bed erosion, and rehabilitate gullies by trapping sediments. In the study areas, farmers commonly practice single row brushwood check-dam. According to field observation, many of the check dams were not constructed well and lacks biological conservation measures that enhance the sediment trapping capacity of the structure figure 10. As a result, check-dams constructed in the study areas were not effective. Mekonen and Tesfahunegn (2011) pointed out that due to deviation of actual check dam from recommended standard the amount of run-off from the up-slope areas of the watershed could not be readily dissipated by the existing check dams, which caused their collapse. This also led to the formation of incisions on the gully floor and sides.

To overcome the failure of the crops due to moisture stress and soil loss, the farmers of study areas are implementing contour furrow. Respondents pointed out that contour furrowing decrease runoff volume thereby enhance water availability to crops. The reduction in runoff volume is attributed to depression storage in the furrows which gives time for infiltration (Gebreegziabher et al., 2009). In the study areas it is commonly practicing on Maize field and farmers used to construct contour furrow 'Shilshalo'by well-experienced oxen. To do so, they use yokes having a different height at planting time and "shilshalo". There is about $10 \mathrm{~cm}$ of height difference exist between yokes (Figure 15). They use the longer yoke for "shilshalo" and the shorter one for plantation and land preparation. Furrow is purposely prepared in a straight line across the slope to harvest rainwater. Besides, there exist width and depth variation among traditional Digir they experience for furrow preparation. Traditional Digirused for Shilshalo has about $30 \mathrm{~cm}$ depth and $50 \mathrm{~cm}$ width where ample of rainwater 
can safely stagnate on the field. So that, at a dry spell, maize crop can face no or little moisture problem. Furthermore, mulching and crop residue management is an important practice in the study areas (Figure 16).

The researcher investigated the practice's effectiveness in terms of reducing soil and water loss caused by runoff and evaporation. Farmers in the study area practice the measure on both farmlands and the home garden. They integrate mulching and crop residue management with zero grazings. The result indicates that farmers commonly practice mulching during the dry season to keep soil moisture, soil from cracking, pulverization and susceptible for erosion, and enhance fertility. Similarly, they practice it during rainy seasons to improve soil structure, reduce raindrop impact, and reduce surface runoff.

Furthermore, the study revealed that farmers practice various measures to replenish soil fertility in the meantime they are used to conserve soil and water. They believe that listed practices are used to improve soil fertility and reduce surface runoff. Selected respondents replied with measures are FYM, composting, green manure, intercropping, row planting, crop rotation, tied ridge, plantation of MPTS, planting deep-rooted crops, and conduct zero and controlled grazing.

\section{Conclusions And Recommendation}

Farmers in the study area are well acquainted with soil erosion, its cause, and consequent reduction in land productivity. They confirm that implementing SWC measures are insurance to sustain and boost soil fertility and land productivity. It is known that SWC measures were begun in Ethiopia in the 1970s and were constructed widely throughout the country, particularly in the Ethiopian highlands. In line with this, various international organizations were invested in this area. Besides, the Ethiopian government and peoples have also invested much more money, time, knowledge, and manpower. But, year by year structures get damage and yet seem not substantial to achieve the sector of sustainable agriculture. The study revealed that various indigenous and introduced soil and water conservation measures had been implementing by farmers at different land-use systems. However, identified practices such as traditional cutoff drain, soil bund, stone-faced soil bund, fanya juu, brushwood, and gabion check-dams have technical, social, and institutional difficulties. The major gap observed with indigenous conservation practices is, it had been taken less attention by different stakeholders including GOs, NGOs, and research institutes. As a result, their respective dimension was not modified, effective measures were not upscaled and circulated to other areas having similar agroecology and farming system. Thus, apparently, traditional conservation measures are aggravating soil erosion and their construction did not consider the downstream effect on dwelling community, water bodies, and aquatic lives. From those cutoff drain is the most known one that forms gully at the boundary and increases size and depth of preexisting gullies since water from cropped lands directly diverts into gullies and waterways without pre stabilization.

Similarly, technical defects on fanya juu and soil bund in terms of channel depth and embankment height was observed and analyzed while evaluating implemented introduced physical conservation measures against standard guideline. This may due to time interval between implementation and evaluation held, free grazing, lack of regular maintenance, improper design and construction, and deliberate destruction by landowners due to shortage and fragmentation of lands. Mostly, in all study areas, in situ soil moisture conservation measures were limited to closed areas and marginally degraded lands alone even in dryland areas of Southern Ethiopia. Thus, based on the finding, the following suggestion is important;

- Adequate consideration might be needed to improve and disseminate technically, economically, socially, and ecologically viable indigenous SWC measures.

- In situ rainwater harvesting measures need to be introduced at the home garden and farm field by integrating them with not only multi-purpose tree and shrub species but also cereal crops to minimize crop failure and boost productivity.

- Appropriate strategies and policy directions for the sustainability of implemented SWC measures should take focus.

\section{Abbreviations}

AARC Areka Agricultural Research Center SWC Soil and Water Conservation

FYM Farm Yard Manure CSA Central Statistical Agency

DAs Development Agents HH Household

ha Hectare FGD Focus group discussion

GOs Government Organizations EBW Embankment bottom width

D Depth EH Embankment height

W Width F Foundation of the bund

ETW Embankment top width B Burm

HB Height of bund DI Diameter of the basin

MTSs Multipurpose Tree Species KII Key Informant Interview

NGOs Non-Governmental Organizations

BoSP Bureau of Statistics and Population 
IFPRI International Food Policy Research Institute

IFAD International Fund for Agricultural Development

SNNPR Southern Nations, Nationalities and Peoples' Region

CARDI Caribbean Agricultural Research and Development Institute

\section{Declarations}

Ethics approval and consent to participate: All authors voluntarily agree to participate in this research study.

Consent for publication: All authors of this paper have read and approved the final version submitted to the Environmental Systems Research.

Availability of relevant data and materials: All relevant data collected was incorporated in the manuscript and it also belongs to the authors. Thus, any author member of this paper can come up with materials regarding the manuscript at any time of necessity.

Competing interests: All authors have no conflict of interest in this manuscript.

Funding (Not applicable)

Authors' contributions: Dawit Kanito has substantial contributions to the design of the work, the acquisition, analysis, interpretation of the result, and writing up a full manuscript. Tsegaye Bekele has also participated in the design of the proposal and data compilation. Tesfaye Dawit and Seyfu T/yohannes have been involved in data collection and provided formal techniques to synthesize study data.

Acknowledgments: We would like to thank Southern Agricultural Research Institute (SARI) for financial support and enriching the paper. Besides, we are also thankful to Areka Agricultural Research Center for facilitating relevant resources to accomplish the study.

Authors' information (Not applicable)

\section{References}

1. Atnafe, A. D., Ahmed, H. M., \& Adane, D. M. (2015). Determinants of adopting techniques of soil and water conservation in Goromti Watershed , Western Ethiopia. 6(6), 168-177. https://doi.org/10.5897/JSSEM15.

2. Bancy M. 2007. 100 ways to manage water for smallholder agriculture in East and South Africa.

3. Bureau of Statistics and Population (BoSP), 2004. Demographic Statistical Abstract. Southern Nation Nationalities and Peoples' Region, Awassa.

4. Caribbean Agricultural Research and Development Institute (CARDI) 2010. Mainstreaming and Capacity Building For Sustainable Land Management: A Manual of Soil Conservation And Slope Cultivation, Pims 3409 -Atlas Project Id 43949.

5. CSA (Central Statistical Agency), 2008. Summary and Statistical Report of the 2007 Population and Housing Census: Population Size by Age and Sex. Federal Democratic Republic of Ethiopia Population Census Commission, Addis Ababa, Ethiopia.

6. CSA (Central Statistical Agency), 2010. Agricultural Sample Survey 2009/2010 (2002 E.C.), Statistical Bulletin, Addis Ababa.

7. Gebreegziabher, T., Nyssen, J., Govaerts, B., Getnet, F., Behailu, M., Haile, M., \& Deckers, J. (2009). Contour furrows for in situ soil and water conservation, Tigray, Northern Ethiopia. Soil and Tillage Research, 103(2), 257-264. https://doi.org/10.1016/j.still.2008.05.021

8. Genene Mekonnen and G/Michael Abiy. 2014. Review on overall status of soil and water conservation system and its constraints in different agro ecology of southern Ethiopia, Journal of Natural Science Research, 4(7): 59-69.

9. Habtamu Olana, 2014. Challenges of Soil and Water Conservation practices and measure to be underatken; the case of Wuchale district, North Shewa Zone, Oromia Regionla State, Ethiopia.

10. Hailay Tsige. 2012. Sustainable land management technologies for SLM Woredas/Region. GIZ SLM program (Sustainable Land Management).

11. Hoben A. (1996). The Cultural Construction of Environmental Policy: Paradigms and Policy in Ethiopia. In Leach and Mears (eds.). The Lie of the Land. Challenging Received Wide on the African Environment. The Internal Africa Institute, London.

12. Hu, G., Liu, H., Yin, Y., \& Song, Z. (2016). The role of legumes in plant community succession of degraded. 372(may 2015), 366-372.

13. Hudson, N.; The factors determining the effect of soil erosion; in: Soil Conservation and Management in the Humid Tropics, edited by Greenland, D. and Lal, R.; pages 11-16; John Wiley and Sons, Chichester, New York; 1977.

14. Hurni H. 1983. Soil formation rate in Ethiopia. Working paper 2. FAO (Food and Agriculture Organization of the United Nations) /MOA (Ministry of Agriculture) joint project, Ethiopian Highlands Reclamation Study, Addis Ababa, Ethiopia.

15. IFAD, 1992. Soil and water conservation in Sub-Saharan Africa. Towards sustainable production by the rural poor. Centre for Development Cooperation Services, Free University, Amsterdam. Hudson, N. 1992. Land husbandry. B. T. Batsford Limited, London. 192 pp.

16. IFPRI (International Food Policy Research Institute), 2006. Atlas of the Ethiopian Rural Journal of the International Association of Agricultural Economics (IAAC), 18(3): 233-247.

17. Mekonen, K., \& Tesfahunegn, G. B. (2011). Impact assessment of soil and water conservation measures at medego watershed in Tigray, northern Ethiopia. Maejo International Journal of Science and Technology, 5(3), 312-330. 
18. Ministry of Agriculture (MoA), 2012. Soil and Water Conservation Training Material Module 7, Ethiopia.

19. Tiki, L., Tadesse, M., \& Yimer, F. (2015). Effects of integrating different soil and water conservation measures into hillside area closure on selected soil properties in Hawassa Zuria. 6(10), 268-274. https://doi.org/10.5897/JSSEM15.0513

20. Wagayehu B and Lars D (2003). Soil and Water Conservation Decision of Subsistence Farmers in the Eastern Highlands of Ethiopia: a case study of the Hunde-Lafto.

21. WFP (2005). Report on the Cost-Benefit analysis and Impact Evaluation of Soil Conservation and Forestry Measurement. MERET. Addis Ababa. Ethiopia.

22. Zheng, F., He, X., Gao, X., Zhang, C., \& Tang, K. (2005). Effects of erosion patterns on nutrient loss following deforestation on the Loess Plateau of China. 108, 85-97. https://doi.org/10.1016/j.agee.2004.12.009

\section{Figures}
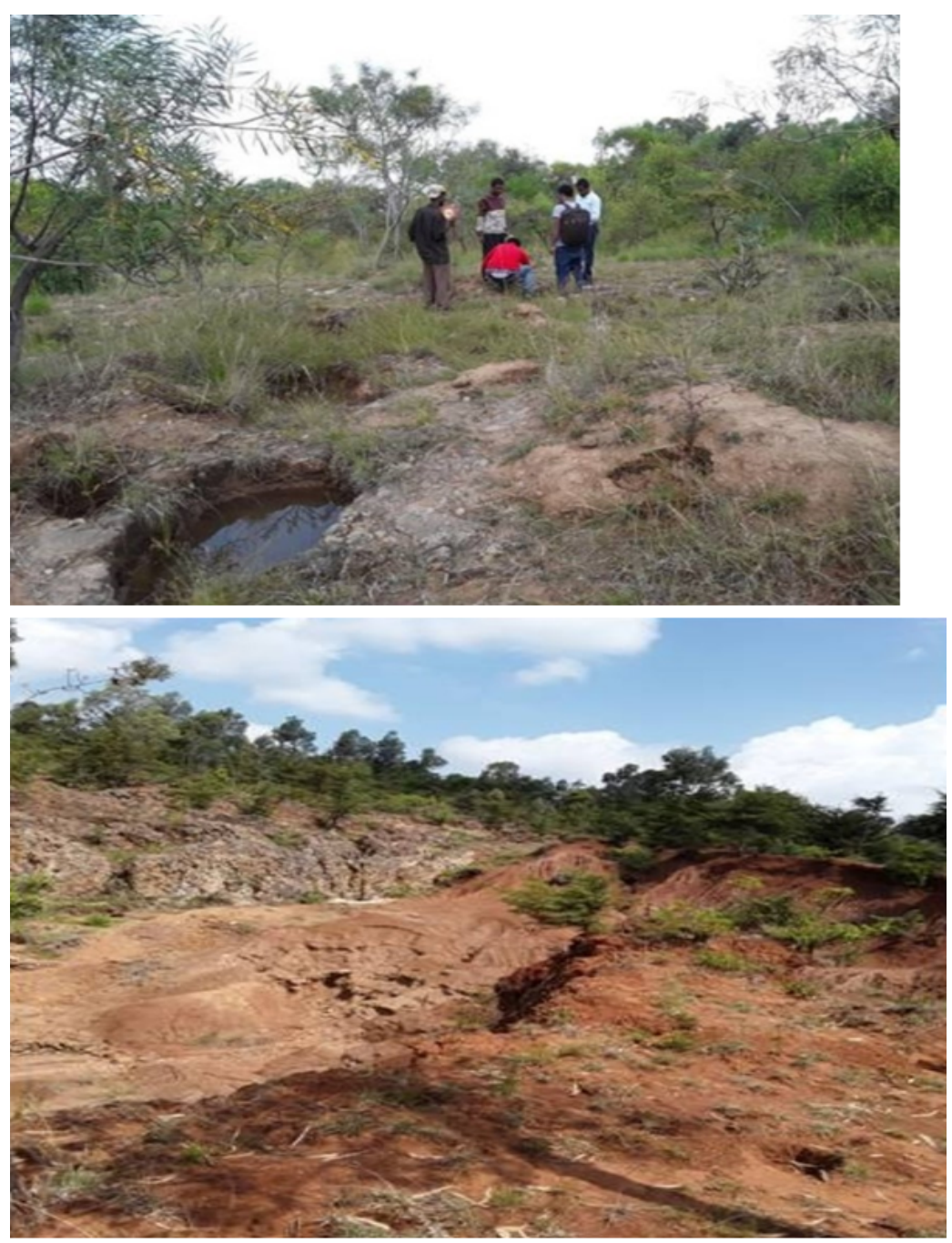

\section{Figure 1}

Area closure in K/Tambaro and Hadiya Zone (Source; field survey, 2018) 


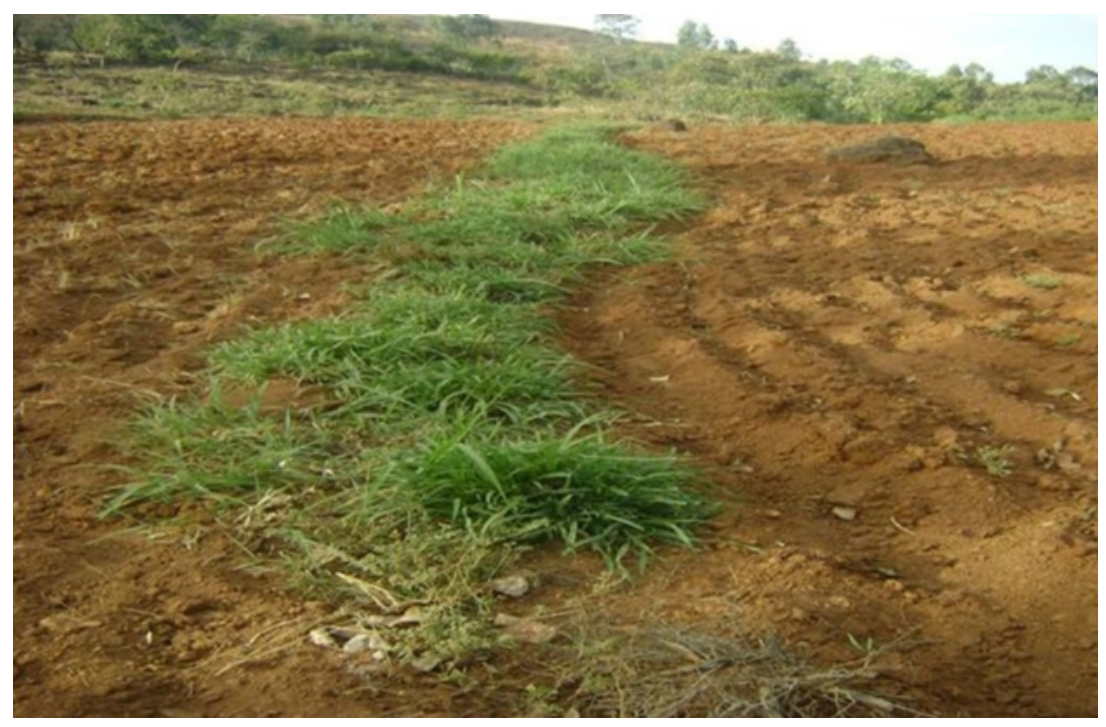

\section{Figure 2}

Grass strip as conservation measures, Wolaita (Source; field survey, 2018)
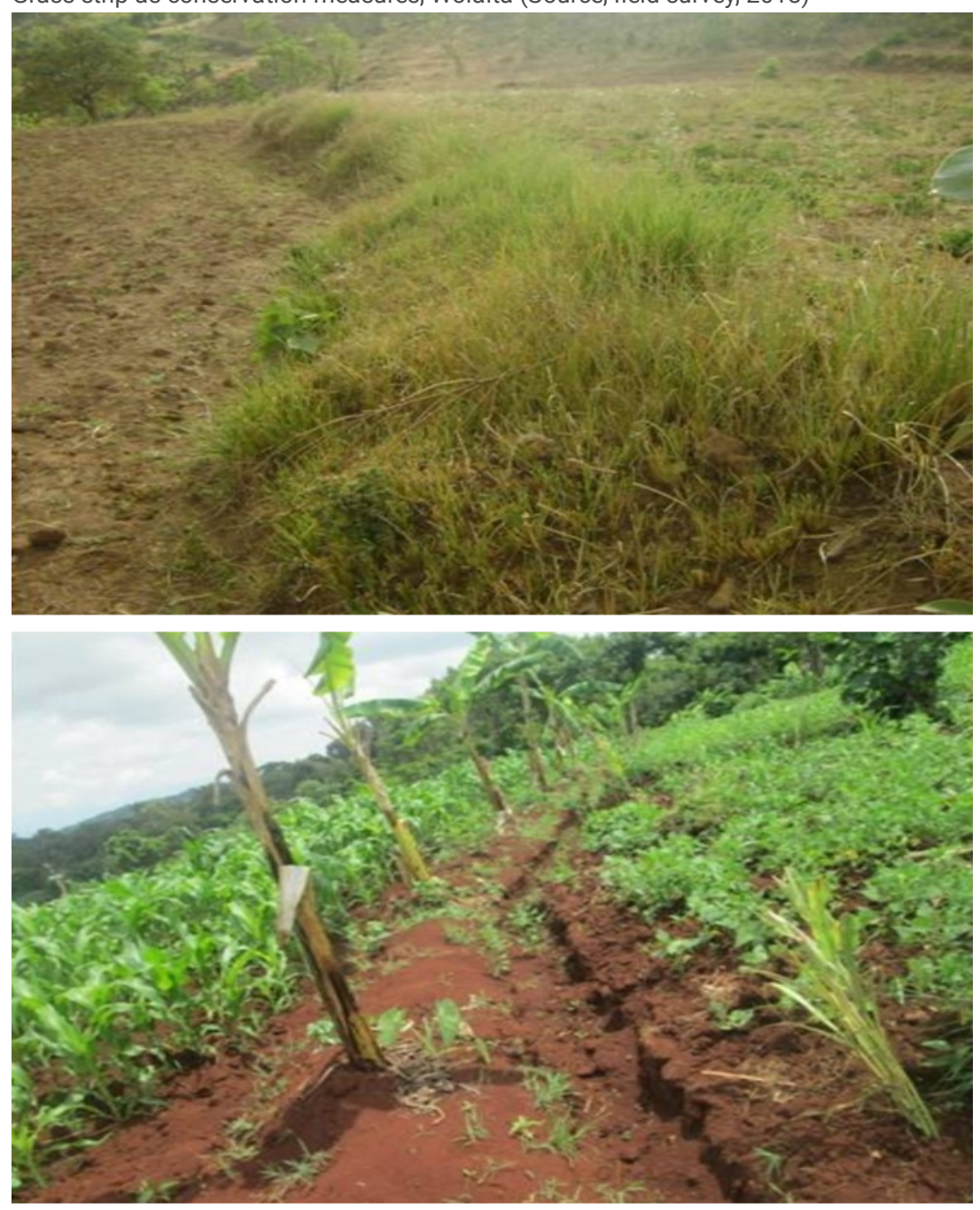

\section{Figure 3}

Bunds stabilized with grass and banana; Wolaita and K/Tambaro (Source; field survey, 2018/19). 

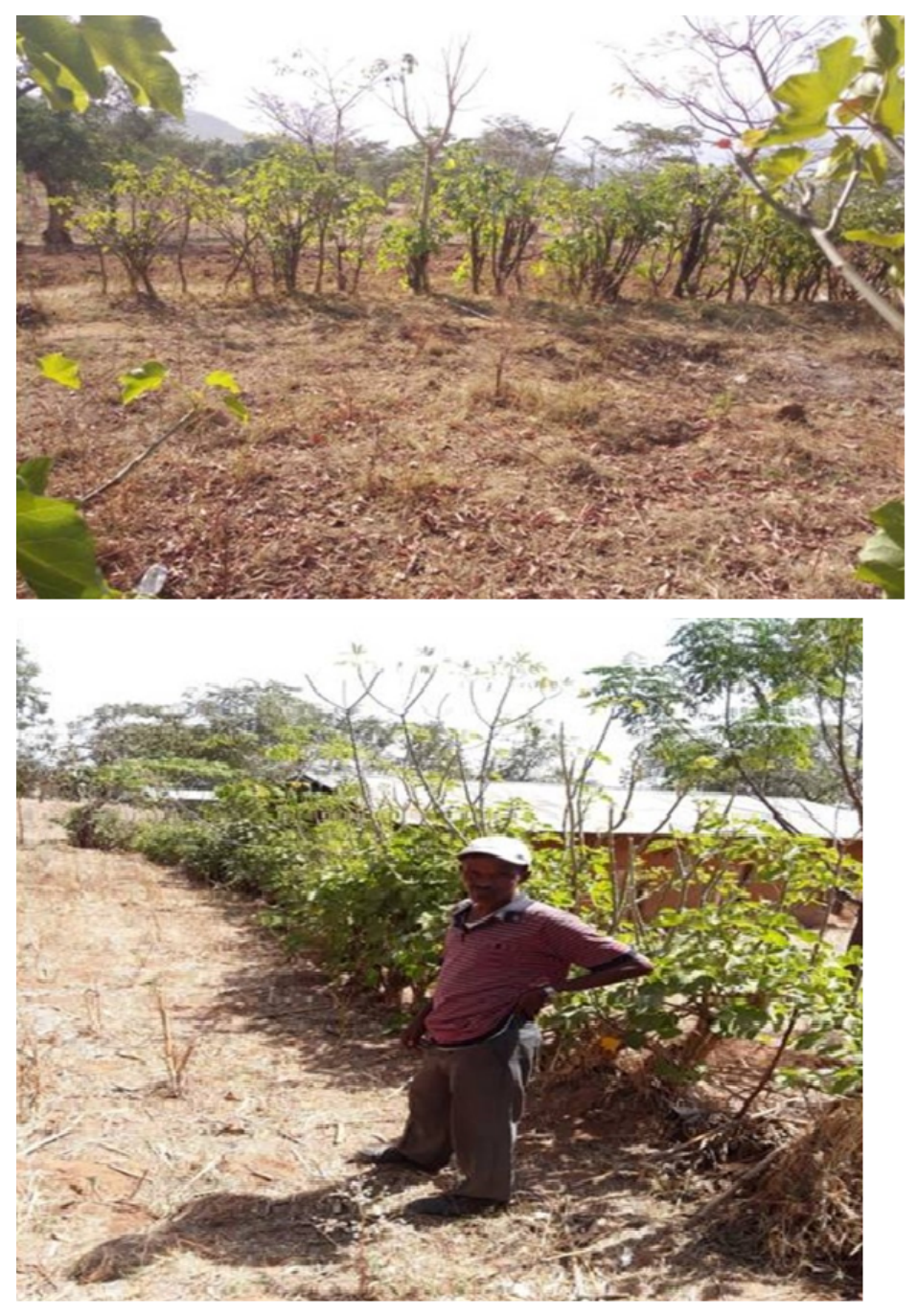

\section{Figure 4}

Live fencing, Dawro (Source; field survey, 2019) 

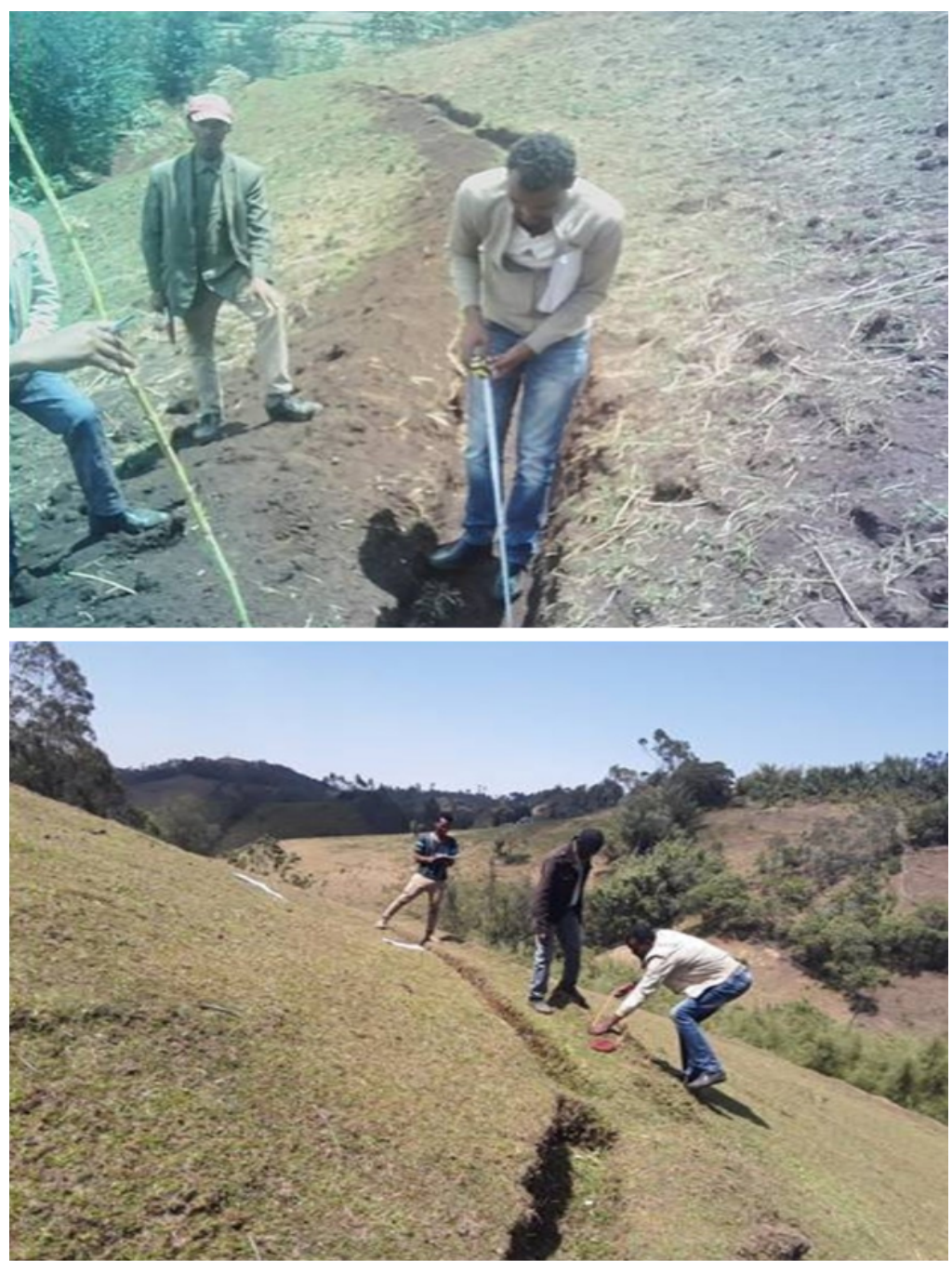

\section{Figure 5}

Field measurement on soil bund, Hadiya and Dawro Zones (Source; field survey, 2019)

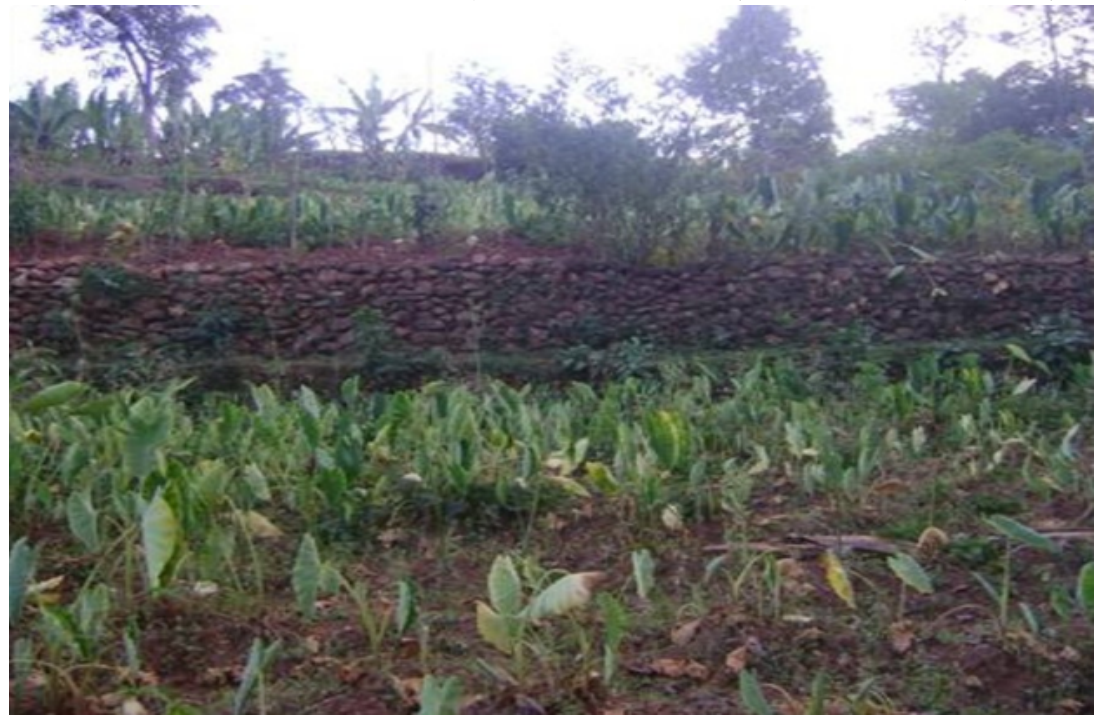

\section{Figure 6}

Stone bund (source; field survey, 2018) photo taken at Wolaita and Dawro 

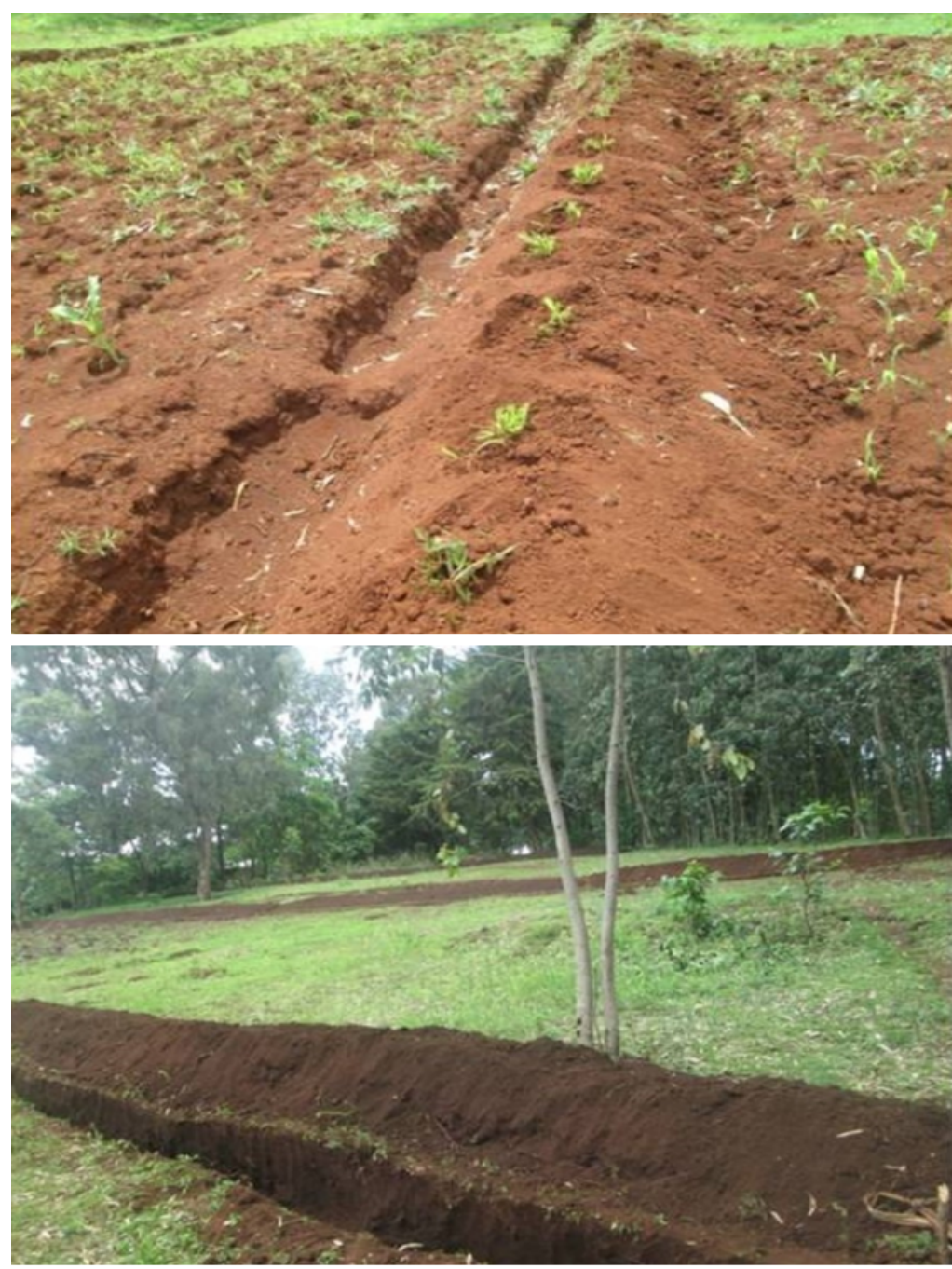

\section{Figure 7}

Fanya juu structure at K/Tamabaro Zone of SNNPR (Source; field survey, 2018/19)

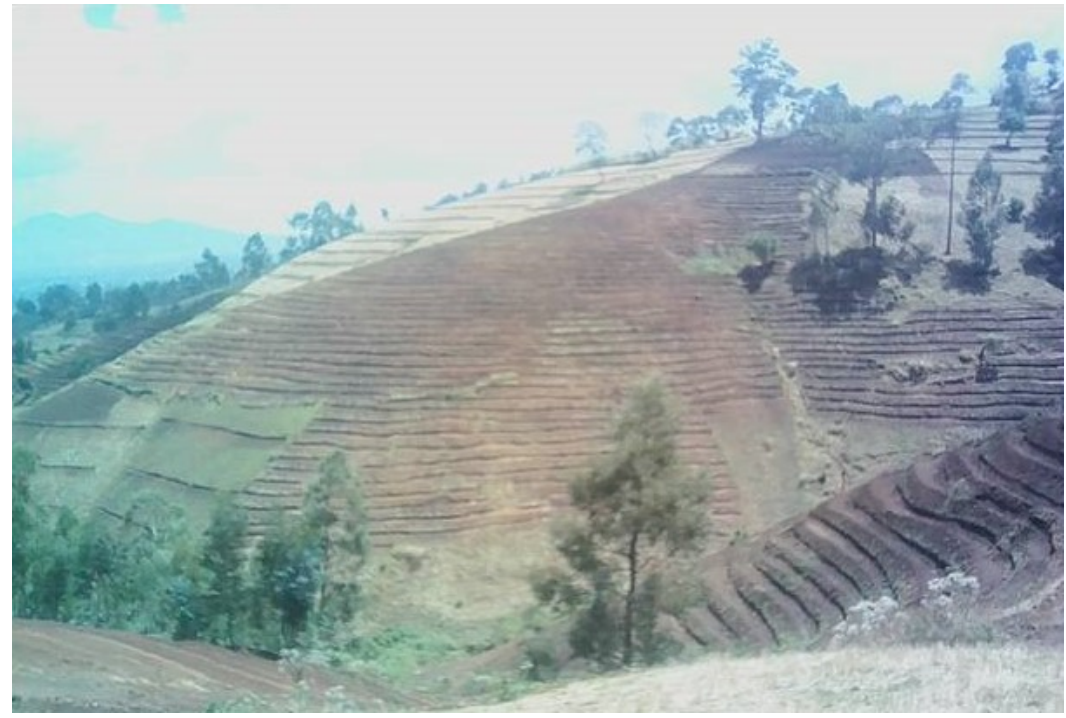

\section{Figure 8}

Hillside terrace at Hadiya (Source; field survey, 2019) 


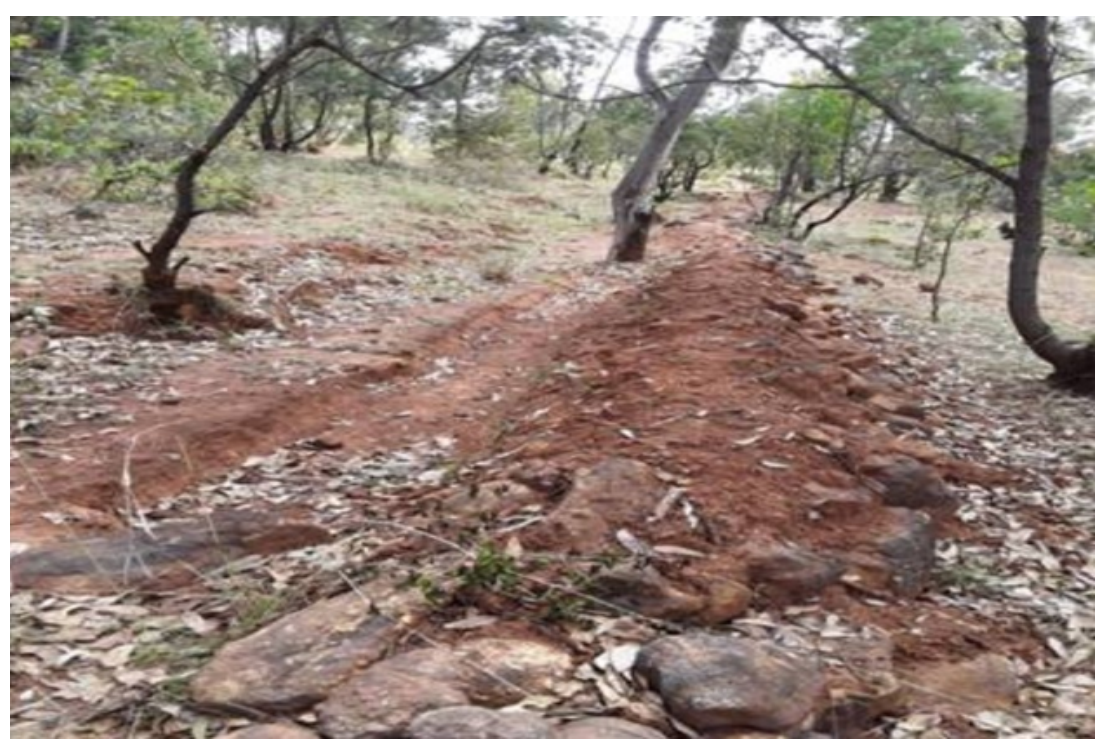

\section{Figure 9}

Stone-faced soil bund Lemo, Hadiya (Source; field survey, 2019)

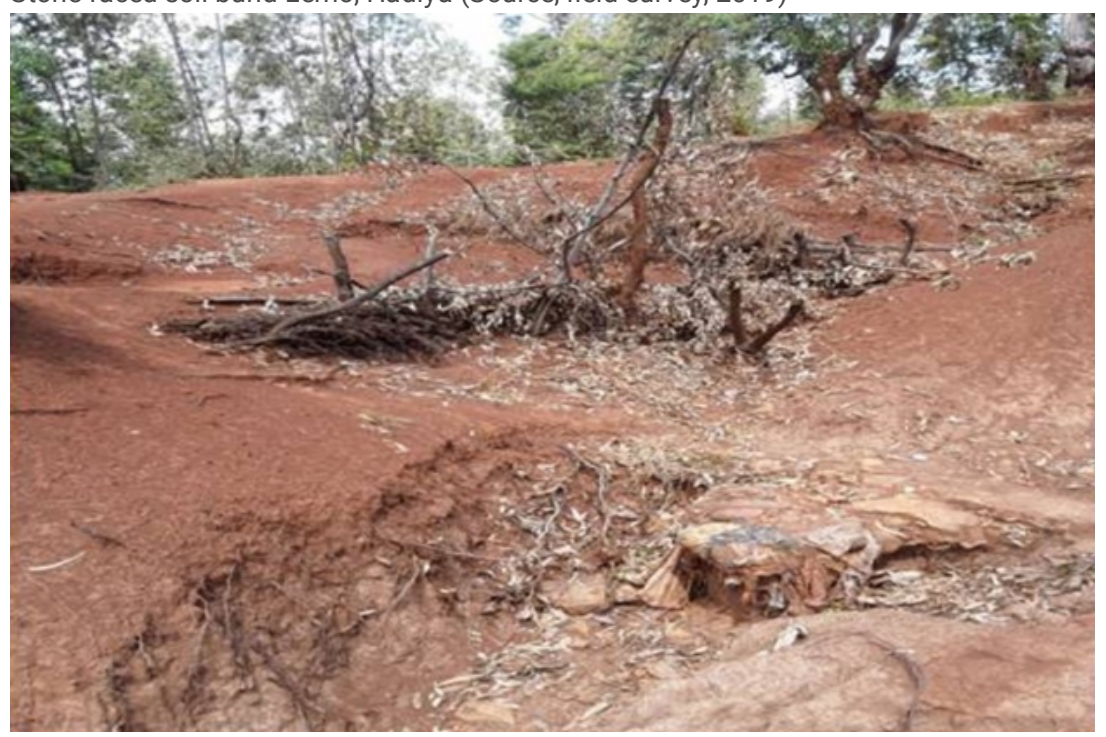

\section{Figure 10}

Brushwood check dam, Lemo, Hadiya (Source; field survey, 2019) 

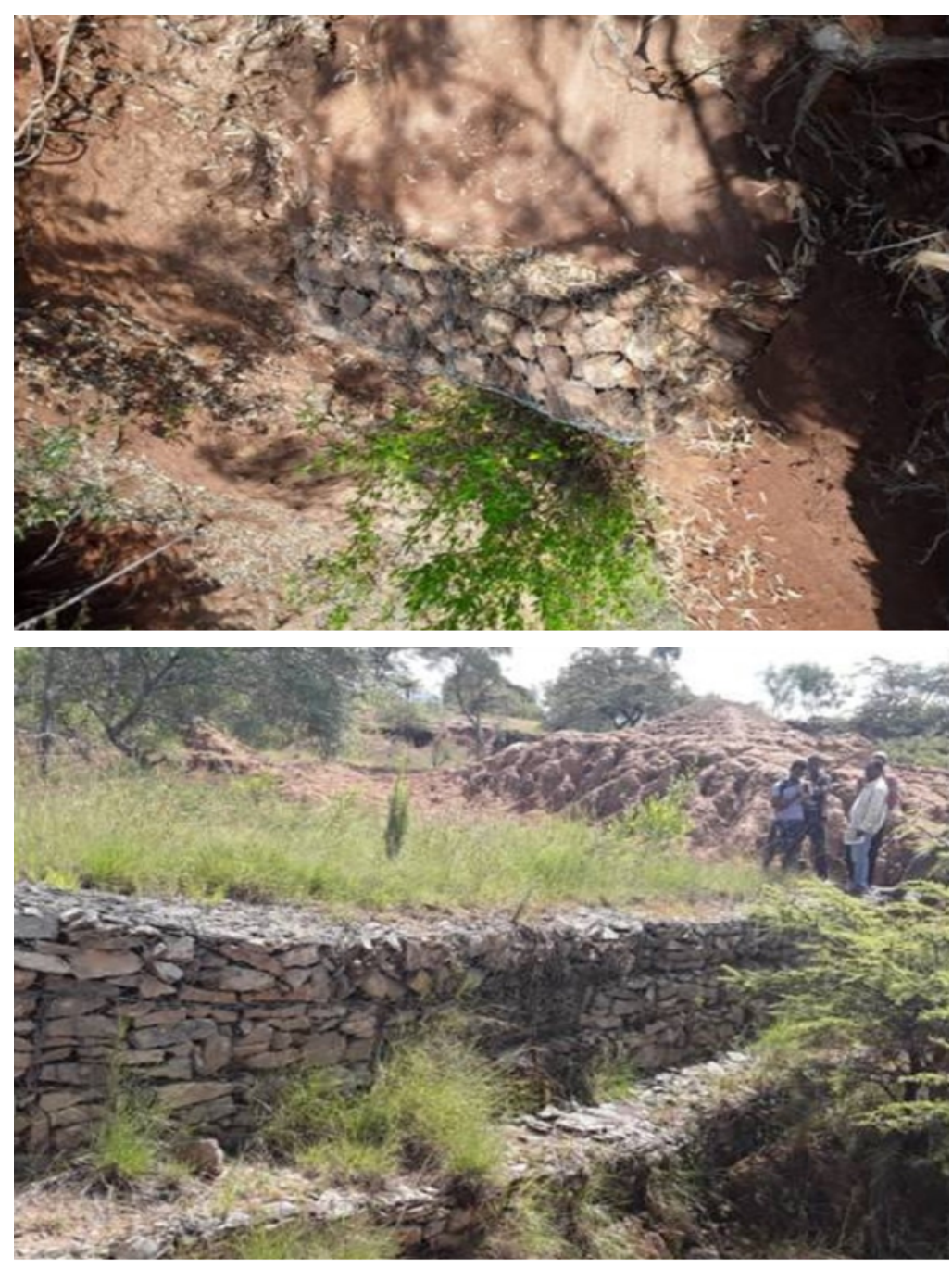

Figure 11

Gabion check-dam, Hadiya and K/Tambaro (Source; field survey, 2019) 


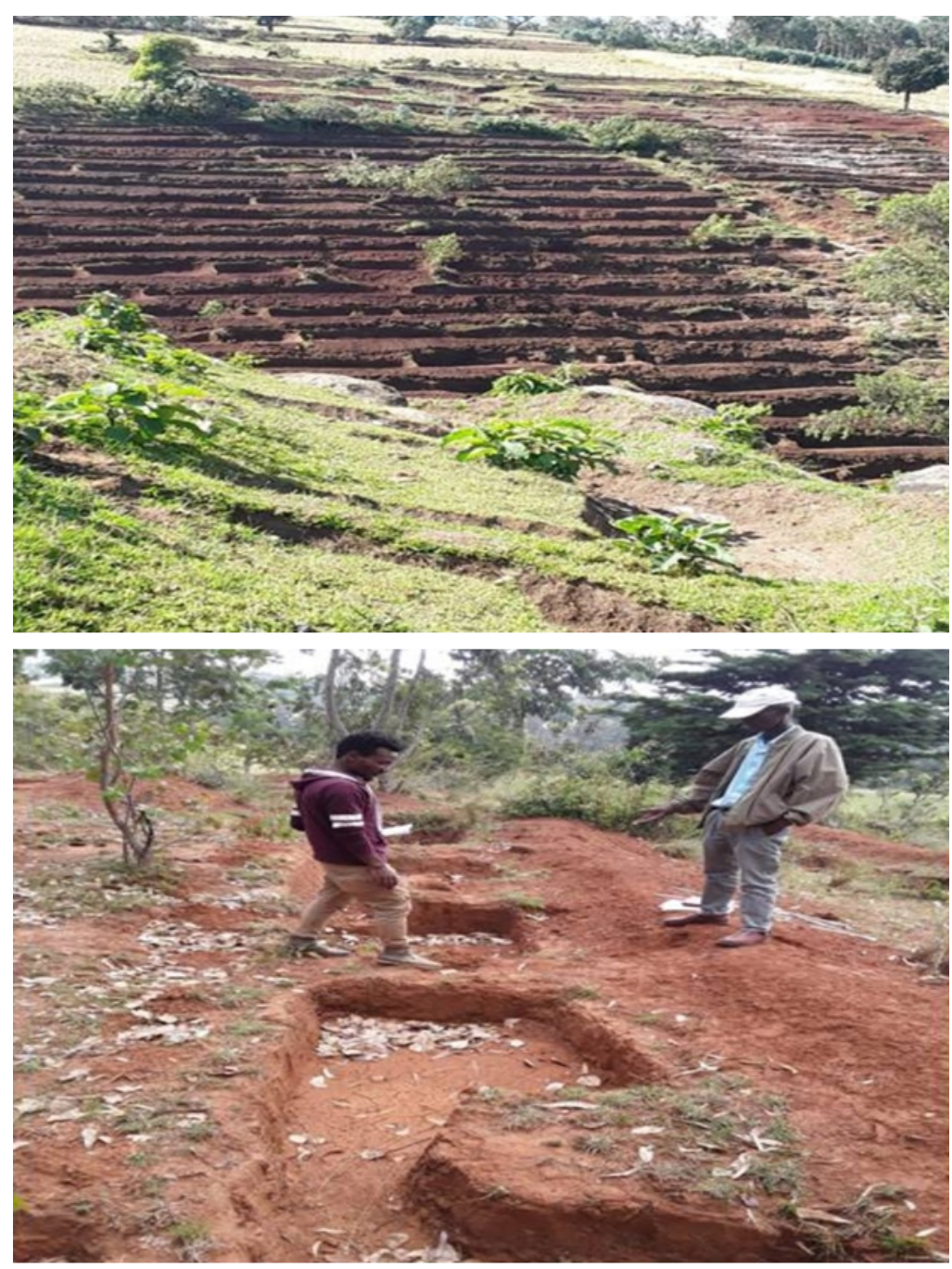

\section{Figure 12}

Shows trenches in Lemu district, Hadiya (Source; filed survey, 2019)

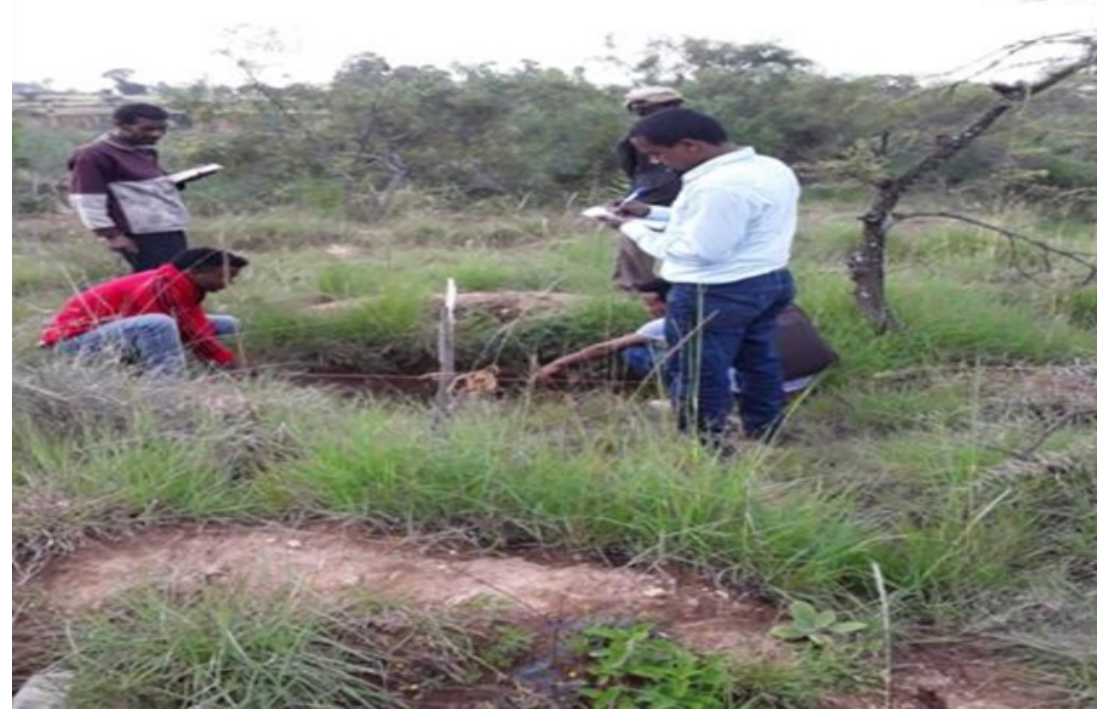

\section{Figure 13}

Shows Micro basin taken at K/Tambaro (Source; field survey, 2019) 


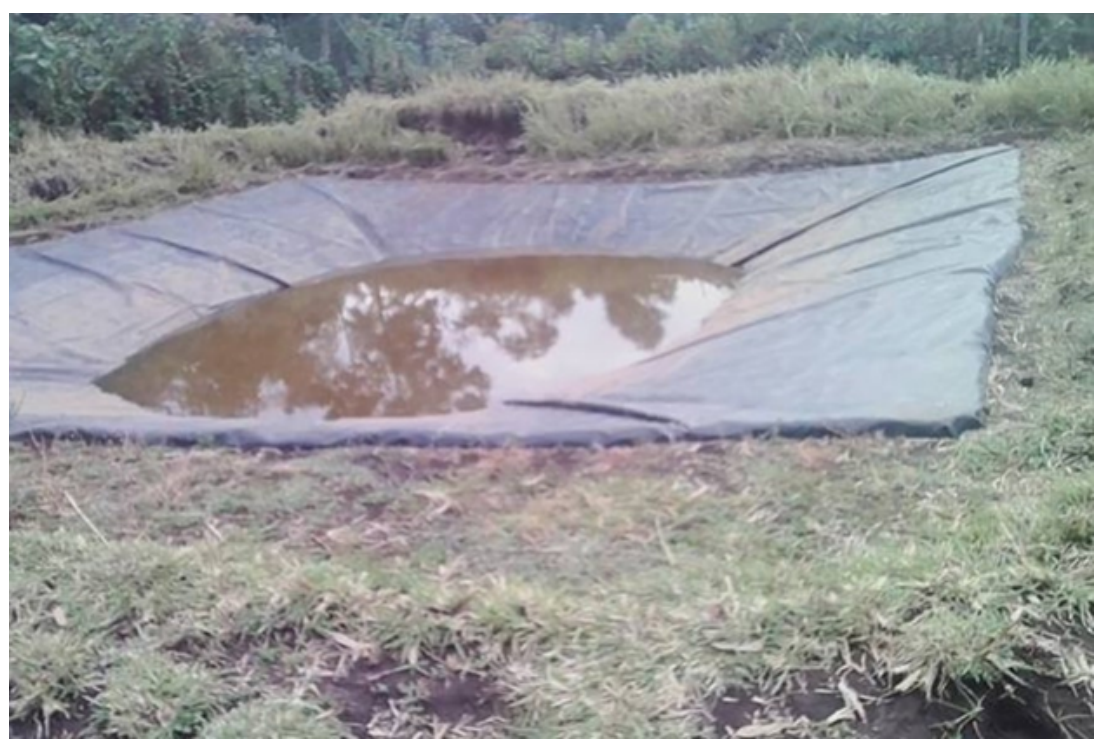

\section{Figure 14}

Communal pond, Hadiya (Source; field survey 2019)
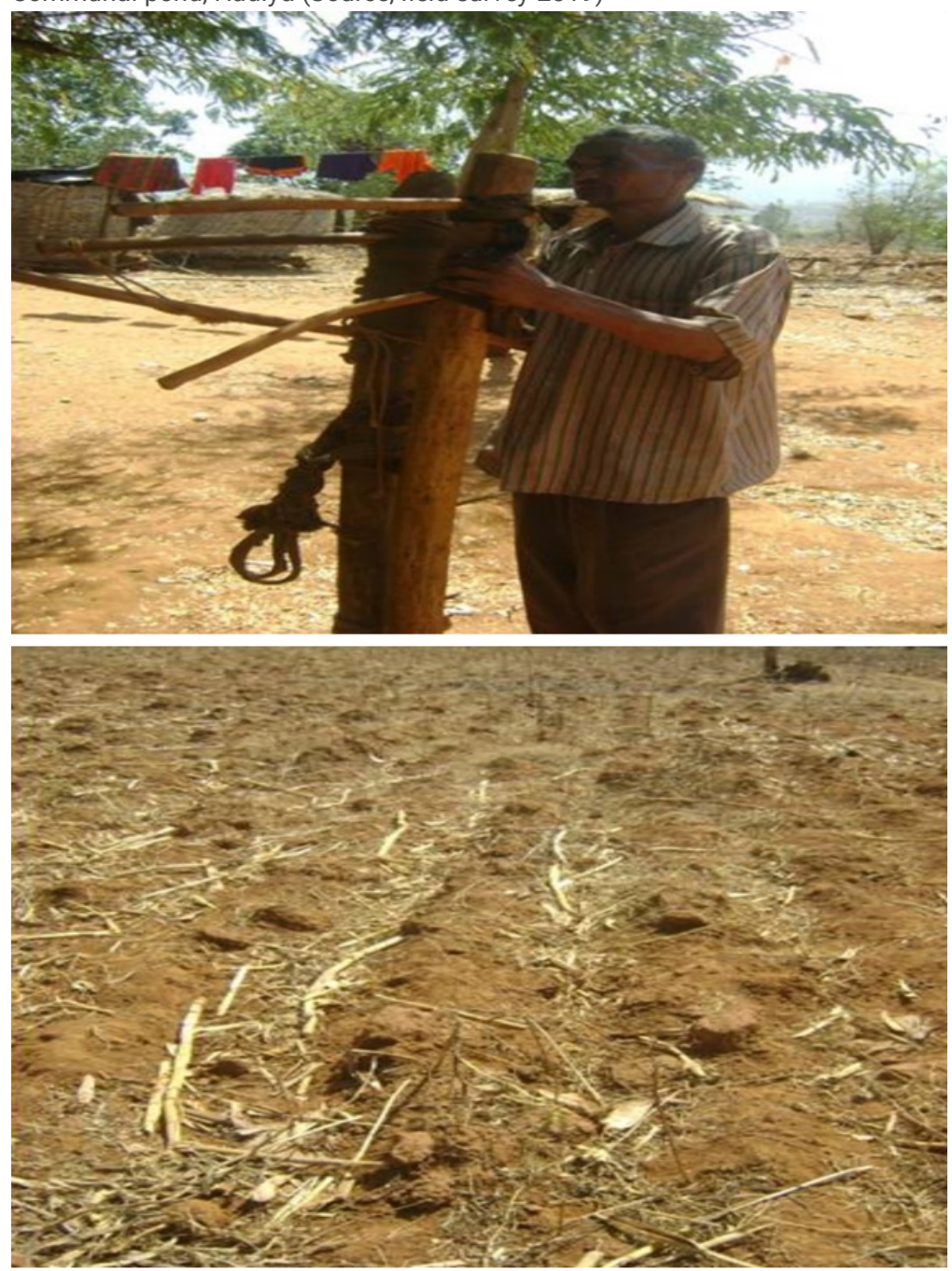

\section{Figure 15}

Different sized Yoke used for shilshalo and plantation, Wolaita (Source; field survey, 2018) 


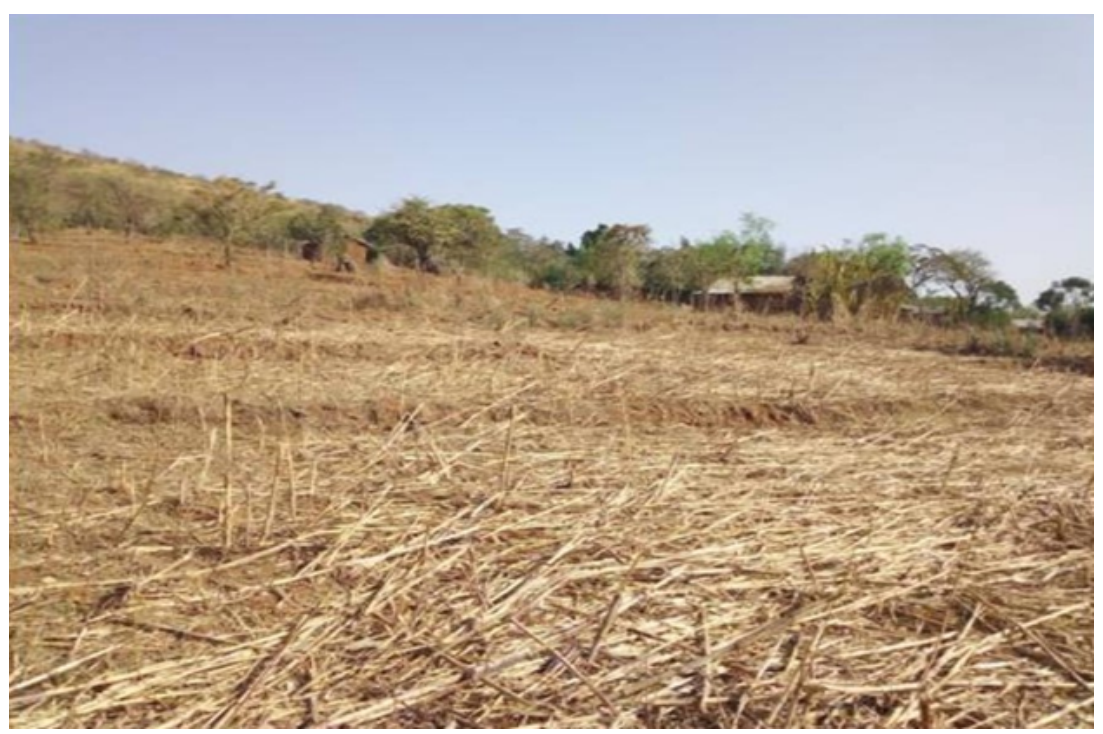

Figure 16

Mulching and crop residue management, Dawro (Source; field survey, 2019)

\section{Supplementary Files}

This is a list of supplementary files associated with this preprint. Click to download.

- Appendix.docx 